\title{
Age, growth, and mortality of the Atlantic goliath grouper Epinephelus itajara in French Guiana
}

\author{
C. Artero ${ }^{1,2, *}$, D. J. Murie ${ }^{3}$, C. C. Koenig ${ }^{4}$, R. Berzins ${ }^{1}$, C. Bouchon ${ }^{2}$, L. Lampert $^{5}$ \\ ${ }^{1}$ Office National de la Chasse et de la Faune Sauvage, BP 10808, 97338 Cayenne Cedex, French Guiana \\ ${ }^{2}$ UMR BOREA, Labex CORAIL, équipe DYNECAR, Université des Antilles et de la Guyane, 97159 Pointe à Pitre, Guadeloupe, \\ French West Indies \\ ${ }^{3}$ University of Florida, Fisheries and Aquatic Sciences, 7922 NW 71 st Street, Gainesville, FL 32653, USA \\ ${ }^{4}$ Coastal and Marine Laboratory, Florida State University, 3618 Coastal Highway 98, St Teresa Beach, FL 32358, USA \\ ${ }^{5}$ Institut Français de Recherche pour l'Exploitation de la MER, Dyneco/Pelagos, 29280 Plouzané, France
}

\begin{abstract}
The age and growth of the Critically Endangered Atlantic goliath grouper Epinephelus itajara of equatorial French Guiana was determined by a non-lethal aging method using dorsal fin rays. Goliath grouper deposit 1 complete annulus per year, with the translucent zone of the annulus laid down at the beginning of the dry season (July). Two readers independently applied the method; there was full agreement between the two for $52 \%$ of the fish, and agreement of $\pm 1 \mathrm{yr}$ for $82 \%$. Comparison of ages derived from paired samples of otoliths and fin rays were identical $(\mathrm{n}=6)$. The mean age of goliath grouper was $4.2 \mathrm{yr}$ (range $=1$ to $17 \mathrm{yr} ; \mathrm{n}=229) ; 82 \%$ of the individuals were under the size/age of sexual maturity. Goliath grouper in French Guiana are larger at a given age and reach their asymptotic length $\left(L_{\infty}=192.3 \mathrm{~cm}\right)$ faster $\left(k=0.20 \mathrm{yr}^{-1}\right)$ than goliath grouper from the west coast of Florida, USA $\left(L_{\infty}=200.6 \mathrm{~cm}, k=0.126\right)$. Total mortality, estimated from a catch curve of the age distribution, was about 0.65 both in the Grand Connetable Island marine protected area in French Guiana (where fishing is prohibited) and outside of the reserve, suggesting that the reserve does not protect goliath grouper from illegal fishing. However, the estimates of total mortality in both fished and protected sites likely includes emigration, because goliath grouper may use rocky sites in French Guiana as a nursery habitat and may not remain there once they mature.
\end{abstract}

KEY WORDS: Epinephelidae $\cdot$ Critically Endangered species $\cdot$ Sclerochronology $\cdot$ Fin rays $\cdot$ MPA

\section{INTRODUCTION}

Atlantic goliath grouper Epinephelus itajara (Lichtenstein, 1822; Epinephelidae), the largest reef fish in the western Atlantic, inhabits rocky reefs from North Carolina (USA) to southern Brazil, including the Gulf of Mexico, Caribbean Sea, and French Guiana (Sadovy \& Eklund 1999). Populations drastically decreased in the late 1980s due to overfishing (McClenachan 2009), leading to the implementation of stricter fishing regulations in many countries, including a total ban in the USA (NMFS 2006) and Brazil (HostimSilva et al. 2005, Gerhardinger et al. 2006b). Listed as

\footnotetext{
${ }^{*}$ Corresponding author: celine.artero.merou@gmail.com
}

Critically Endangered in the IUCN Red List of Threatened Species (Craig 2011), goliath grouper in French Guiana still supports both recreational and commercial fisheries. However, the effect of these fisheries on the sustainability of the goliath grouper stock is unknown because there is a lack of landing data and no stock assessment to date.

Goliath grouper in French Guiana are caught primarily by hook-and-line, but incidental captures also occur in fishing nets. Fishermen have reported a decrease in both the frequency of capture and total length of goliath grouper, although official surveys of commercial landings by the Institut Français de

(C) The authors 2015. Open Access under Creative Commons by Attribution Licence. Use, distribution and reproduction are unrestricted. Authors and original publication must be credited. 
Recherche pour l'Exploitation de la Mer (Ifremer) only began in late 2005, not long enough to establish reliable population trends. Based on these surveys, the unregulated goliath grouper commercial fishery represented 1 to $2 \%$ of total fish landings, about $33 \mathrm{t}$ per year (Ifremer data). No information exists on recreational catches, but since 2010 the capture of goliath grouper has been limited to 1 ind. per boat per day by the prefecture of French Guiana (Decree no. 1641/2010) to prevent illegal commercialization.

Ecological and behavioral studies of goliath grouper are lacking in French Guiana. The majority of information about the species has come from Florida and Brazil, where studies have been ongoing since the late 1990s. Goliath grouper are known to form spawning aggregations (Bullock et al. 1992, Sadovy \& Eklund 1999, Gerhardinger et al. 2006a), similar to other grouper species (e.g. black grouper, Mycteroperca bonaci; yellowmouth grouper, $M$. interstitialis; and Nassau grouper, Epinephelus striatus). Aggregating behavior, in combination with life history characteristics of long life, slow growth, and late sexual maturity, makes them vulnerable to overfishing (Sadovy \& Severin 1992, Coleman et al. 1996, Koenig \& Coleman 2009).

Conservation of the exploited goliath grouper stock in French Guiana depends on knowledge of their ecology and life history. Information such as age and length distributions, growth rate, age and size at sexual maturity, and reproductive patterns is critical to stock management but is completely lacking in French Guiana. Bullock et al. (1991) studied age and growth of goliath grouper from the eastern Gulf of Mexico where the oldest fish sampled was $37 \mathrm{yr}$ old and $216 \mathrm{~cm}$ total length (TL). Size at maturity of goliath grouper in the Gulf of Mexico population was 110 to $115 \mathrm{~cm}$ TL for males and 120 to $135 \mathrm{~cm}$ TL for females (Bullock et al. 1992, Sadovy \& Eklund 1999). For the most part, knowledge of the reproductive patterns of goliath grouper has come from studies conducted in Florida. Although protogyny is common among species in the genus Epinephelus (Shapiro 1987), it is unknown if it occurs in goliath grouper throughout its range (Sadovy \& Shapiro 1987, Bullock et al. 1992, Sadovy \& Eklund 1999). For example, Bullock \& Smith (1991) found no evidence of protogyny in specimens examined from the Gulf of Mexico, but Koenig \& Coleman (2013) showed protogyny to be common among goliath grouper on the Atlantic coast of Florida. No individuals in reproductive condition have been found in French Guiana to date, either by commercial or recreational fishermen or through scientific studies.
Age is typically determined in fishes by analyzing growth rings in otoliths ('ear stones'), structures in the middle ear that are formed by laying down layers of calcium carbonate that can be distinguished as annual rings, or annuli, based on seasonal growth. The disadvantage of using otoliths to age a fish is that it is a lethal method that is not appropriate for critically endangered species. Fortunately, a non-lethal method of aging goliath grouper has been developed using dorsal fin rays (Murie et al. 2009). Ages of goliath grouper using otoliths and fin rays from the same individuals were found to be comparable to the age of $18 \mathrm{yr}$ (older individuals were not available) for fish sampled off the east coast of Florida (Murie et al. 2009). However, the ability to apply this methodology to age goliath grouper using fin rays or otoliths in French Guiana was uncertain at the outset of this project because of the region's equatorial location, where the seasonal variation is usually minimal and hence the annuli in the aging structures may be indiscernible.

Estimates of total mortality $(Z$; the combined mortality due to fishing, $F$, and natural sources, $M$ ) (Ricker 1975), are used in stock assessments to determine sustainable harvest levels of exploited species and rebuilding plans for over-exploited species. Direct evaluation of the rates of $F$ and $M$, is therefore important for the successful management of fish stocks. This study had the advantage of sampling goliath grouper from a no-take marine protected area (MPA; Grand Connetable Island Reserve), which could be compared to areas outside of the MPA that were routinely fished. This allowed us to calculate total mortality within the MPA and compare it with that outside the MPA using age and length distributions. In the MPA, total mortality was assumed to be equal to natural mortality (i.e. $F=0$, therefore $Z=M$ ).

The overall goal of this study was to estimate the age, growth and mortality of goliath grouper in French Guiana. Specific objectives were to (1) determine whether or not fin rays of goliath grouper in tropical French Guiana have a discernable pattern of growth that can be used as an aging method, and if so, to validate this aging method; (2) determine growth patterns of goliath grouper in French Guiana, and to compare these patterns with those of other locations where growth patterns have been observed; (3) estimate total, natural, and fishing mortality of goliath grouper in French Guiana; and (4) discuss life history patterns and mortality relative to the sustainability of the goliath grouper fishery in French Guiana. 


\section{MATERIALS AND METHODS}

\section{Sample collection and processing}

A total of 615 goliath grouper were captured in French Guiana (Fig. 1) from July 2010 to September 2013, except in January to April from each year when fishing was not possible due to sea conditions. Groupers were caught by hook-and-line and released alive, with the exception of 6 ind. (2 from recreational fishermen and 4 from commercial fishermen) that were sacrificed to collect paired samples of otoliths and fin rays. All specimens were captured between 0 and $20 \mathrm{~m}$ depth, which is the depth range of rocky sites along the French Guiana coast. Goliath grouper were caught by hook-andline with the same hook and leader sizes for the entire study.

Each released fish was measured for TL $( \pm 1 \mathrm{~cm})$ and marked by inserting a numbered plastic spaghetti tag (Floy Tag \& Manufacturing) into the base of the second dorsal fin. Fish $(n=229)$ were then sampled for fin rays by excising fin rays 5 and 6 from their second dorsal fin, as close as possible to their articulation point. Recreational fishermen of the Association des Plaisanciers et Pêcheurs de Guyane (APPG) were also instructed on how to sample fish and contributed to the data collection. When tagged fish were recaptured, the adjoining fin rays ( 7 and 8 ) were removed to re-age the fish. Fin rays were put on ice in the field and then transferred to a freezer in the laboratory until processed for aging.

Fin ray aging of goliath grouper followed the protocol of Murie et al. (2009) with modifications specific to goliath grouper in French Guiana. Thawed fin rays were cleaned by immersing them in simmering water for $\sim 2$ min and then mechanically removing the remaining skin and muscle tissue. Fin rays were then dried in an oven at $60^{\circ} \mathrm{C}$ for $24 \mathrm{~h}$ and stored in envelopes. For otoliths, both sagittal otoliths were removed, rinsed in water, and stored dry in vials until sectioned. Fin rays and otoliths were processed in the fish aging laboratory at the University of Florida Department of Fisheries and Aquatic Sciences in Gainesville. Cleaned and dried fin rays were embedded in epoxy resin (Loctite ${ }^{\circledR}$ ) and cross-sectioned at a thickness of 1.2 to $1.7 \mathrm{~mm}$ using a high speed $(625 \mathrm{rpm})$ sectioning machine (Isomet 1000) with a $152 \mathrm{~mm}$ diameter diamond-wafering blade. Four or more adjacent cross-sections were cut from the base of each fin ray, rinsed with distilled water, and then mounted on a glass microscope slide. Sections were air dried for $24 \mathrm{~h}$ and then permanently mounted with Flotexx ${ }^{\circledR}$. For processing otoliths, the left sagittal otolith of each fish was adhered to a fullyfrosted glass slide with hot glue and then cross-sectioned using the Isomet 1000 saw at $325 \mathrm{rpm}$ with a $76 \mathrm{~mm}$ diameter diamond-wafering blade. Cross-sections $0.5 \mathrm{~mm}$ thick were taken through the core of the otolith, and permanently mounted on a glass slide using Histomount ${ }^{\circledR}$.

\section{Age determination}

Annuli were counted using a stereomicroscope at variable magnification (20 to $200 \times$ ) using transmitted light. A complete annulus (ring) is equivalent to 1 opaque zone plus 1 translucent zone (Caillart \& Morize 1989, Bullock \& Murphy 1994, Crabtree \& Bullock 1998). Annuli are linked to the growth rate variation induced by environmental or endogenous factors. Usually, opaque zones are formed during periods of fast growth whereas translucent zones are formed when the growth rate slows. Opaque zones are counted in otoliths whereas translucent zones are counted in fin rays because they are more easily seen. However, for paired comparisons between otolith and fin rays, the opaque zones were counted in each structure.

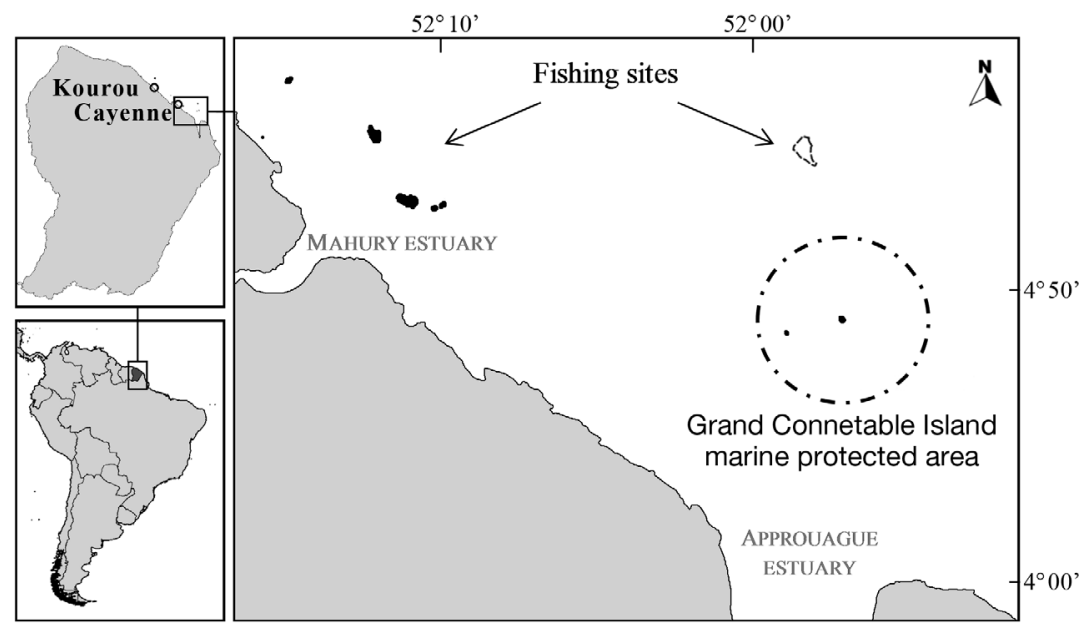

Fig. 1. Sampling areas for Atlantic goliath grouper Epinephelus itajara in French Guiana showing the boundary (circle) of the Grand Connetable Island marine protected area $\left(87 \mathrm{~km}^{2}\right)$, where fishing is prohibited. For the fishing sites, white delimited areas: submerged rock; black areas: rocky islands 


\section{Validation}

We used marginal increment analysis to validate annulus deposition in fin rays. The marginal increment was denoted as: '-' for a translucent zone on the edge of the aging structure, ' + ' for an opaque zone on the edge of the structure that was $<1 / 3$ the width of the previously completed growth increment, ' ++ ' for the opaque zone on the edge that was $1 / 3$ to $2 / 3$ the width of the previously completed increment, and ' +++ ' for an opaque zone on the edge $>2 / 3$ the previous increment. The percentage of fish with each category of marginal increment was plotted as a function of month of the year to determine the annual pattern of annulus formation. In addition, the overall percentage of fish with either a translucent or opaque margin was plotted as a function of month of year in an edge analysis. Plots that showed only 1 minimum in a 12 mo period would indicate that only 1 complete annulus (1 translucent +1 opaque zone) was deposited that year; 2 minima would indicate that 2 annuli were deposited. Although goliath grouper in Florida are known to deposit only 1 annulus $\mathrm{yr}^{-1}$, some fish species in tropical regions are known to deposit 2 annuli $\mathrm{yr}^{-1}$ (biannuli) (Rao \& Rao 1986, Admassu \& Casselman 2000, Bwanika et al. 2007) and so it was important to determine the deposition pattern in goliath grouper from equatorial French Guiana.

Annulus deposition rate was also validated directly using recaptured fish. Fin rays from recaptured fish were aged and compared to their age at their original capture, if the fish was recaptured at least $1 \mathrm{yr}$ after tagging and release. The number of annuli at first capture was subtracted from the number of annuli at recapture and compared to the number of years that the fish had been at large since tagging.

\section{Accuracy}

Under the assumption that the otolith age represents the actual age of the fish, we determined accuracy of fin ray aging by comparing fin ray ages with otolith ages from 6 sacrificed individuals caught by professional fishermen. All readings were independent and done without knowledge of collection date or size of fish.

\section{Precision}

To determine precision, each fin ray was read independently 3 times by the same reader (Reader 1 ). If at least 2 counts of the 3 were the same, then the dominant count was chosen as the resolved age. When each of the 3 counts was different, then the fin ray was aged again and if any 2 readings agreed then that result was chosen as the resolved age. To estimate precision among readings, the percent coefficient of variation (CV) was calculated (Kimura \& Lyons 1991):

$$
\% \mathrm{CV}=(\mathrm{SD} / \mathrm{x}) \times 100
$$

where SD is the standard deviation of counts for a given fin ray and $x$ is the mean annulus count for the given fin ray. In addition, 62 fin rays $(27 \%$ of the total fish sampled) were aged once by a second experienced independent reader (Reader 2), and reader agreement was compared using percentage of agreement.

\section{Growth}

A von Bertalanffy growth curve was fitted to the age and length data using a non-linear regression with least-squares estimation as the loss function ( $R$ software) as:

$$
L_{t}=L_{\infty}\left(1-\mathrm{e}^{-\mathrm{k}\left(t-t_{0}\right)}\right)
$$

where $L_{t}$ is the total length (cm) at age $t_{i} L_{\infty}$ is asymptotic length $(\mathrm{cm}) ; k$ is the Brody growth coefficient $\left(\mathrm{yr}^{-1}\right) ; t$ is the age $(\mathrm{yr}) ;$ and $t_{0}$ is the theoretical age when length is zero. Ages of fish used in the model were based on the age class of each fish, which is the observed age corrected for time of capture relative to an international birthdate of 1 January. Assigning fish into age classes ensured that cohorts, or fish born in the same year, were not split between years. Fractional ages, or ages that take into account the capture date of the fish relative to its actual birthdate, could not be calculated because it is currently unknown when (or if) goliath grouper spawn in French Guiana.

\section{Mortality}

Catch curves for fish sampled in French Guiana were constructed by plotting the $\log _{e}$ of the number of goliath grouper caught against their age class (Ricker 1975). For those fish in which age was not determined (386 ind.), an age-length key (Fridriksson 1934) was used to estimate their age. Only age classes fully recruited to the sampling gear (i.e. the age classes in the descending limb of the catch curve), were used to estimate mortality (Pauly 1990). Ages in the catch curve represented by $<5$ ind. 
were also eliminated (Chapman \& Robson 1960). Z was estimated by the slope of a linear regression through the descending right limb of the catch curve (Ricker 1975). Differences in $Z$ among years (2010 to 2013) were tested by analysis of covariance (ANCOVA). $Z$ was also compared for goliath grouper captured outside of the MPA relative to fish captured inside the MPA, where $Z$ was assumed to be equivalent to $M$ due to the prohibition of fishing in the MPA and because no inter-site movements were recorded during the present study. Overall mortality of goliath grouper captured inside the MPA was subtracted from that outside the MPA to estimate overall fishing mortality $(Z-M=F)$ for goliath grouper in French Guiana. larger opaque zones at the fin ray margin. Edge analysis, which combined all the opaque zone codes in comparison to the translucent zone, was unimodal and indicated that the translucent zone in fin rays was deposited primarily during May through August (Fig. 4B). In addition, direct validation of annulus formation came from recaptured fish. For 2 fish that were recaptured 1 yr after their initial tagging, the annuli had correspondingly increased by 1 annulus. Comparison of ages between otoliths and fin rays from the same individuals (6 in total) were in complete agreement. Their ages ranged from 1 to 6 yr old.

Within the primary reader (Reader 1 ), there was $62 \%$ total agreement $(\mathrm{CV}=9.9 \%)$ between the first 2 readings and $69.5 \%$ agreement $(\mathrm{CV}=8.3 \%)$ between the second and third readings. A total of 45 fin

\section{RESULTS}

Goliath grouper caught inside the boundaries of the MPA (Fig. 1) ranged in size from 78 to $189 \mathrm{~cm}$ TL $(\mathrm{n}=158)$, with the majority of fish between 80 and $159 \mathrm{~cm}$ in length (Fig. 2). Fish captured in areas outside of the MPA ranged between 38 and $203 \mathrm{~cm}$ in length $(\mathrm{n}=71)$, most of which were 81 to $152 \mathrm{~cm}$ in length (Fig. 2). Length frequencies of the 2 groups of goliath groupers were not significantly different from one another (KolmogorovSmirnov, $\mathrm{p}>0.05$ ).

\section{Age}

Growth rings were visible in all fin ray sections (Fig. 3A) but became sequentially closer together at the edge of the fin rays in older fish (Fig. 3B), making these individuals more difficult to age. Some had numerous false annuli or 'checks' in their first few years, also creating some difficulties in consistently aging the fish. Validation of a single annulus forming each year was clear from the plot of marginal increment codes by month (Fig. 4A) and the overall edge analysis (Fig. 4B). During July, about $50 \%$ of the fish showed a new translucent zone forming at the margin of the fin ray. From November to December, the majority of fish showed sequentially

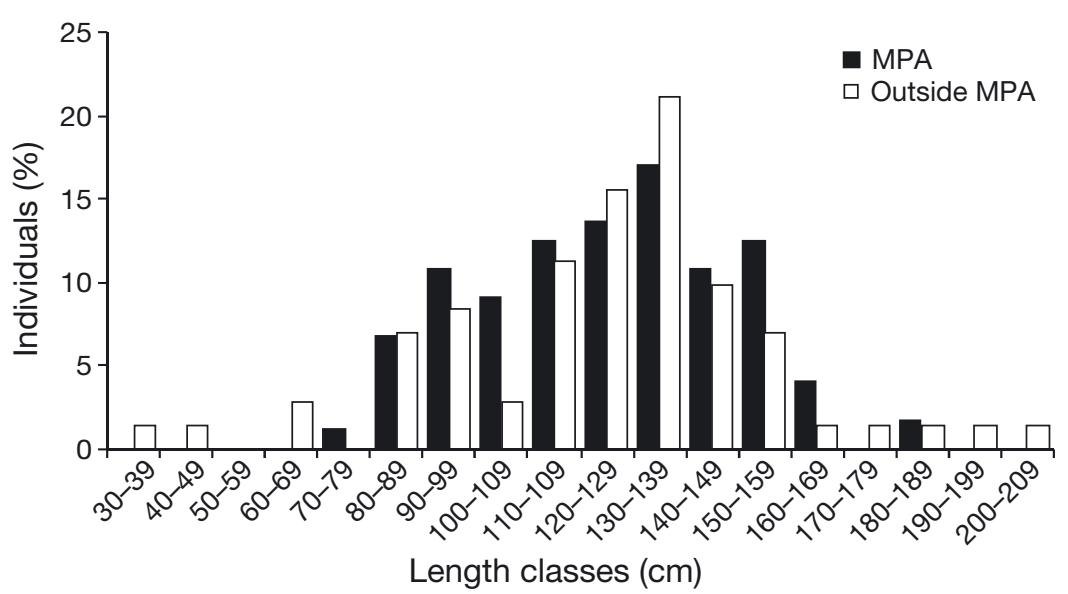

Fig. 2. Length frequencies of Atlantic goliath grouper Epinephelus itajara in French Guiana captured within the boundaries of the Grand Connetable Island marine protected area (MPA) and from areas outside of the MPA

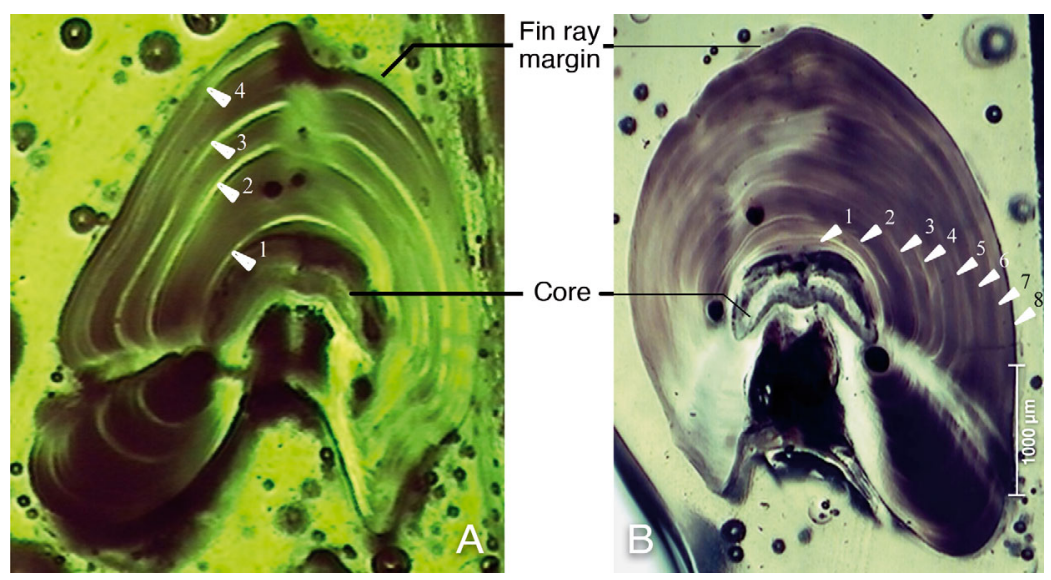

Fig. 3. Fin ray aging of Atlantic goliath grouper Epinephelus itajara from French Guiana, showing clear translucent and opaque zones in (A) a 4 yr old fish (picture taken with green filter), and (B) an 8 yr old fish, where the annuli compact at the edge of the aging structure 


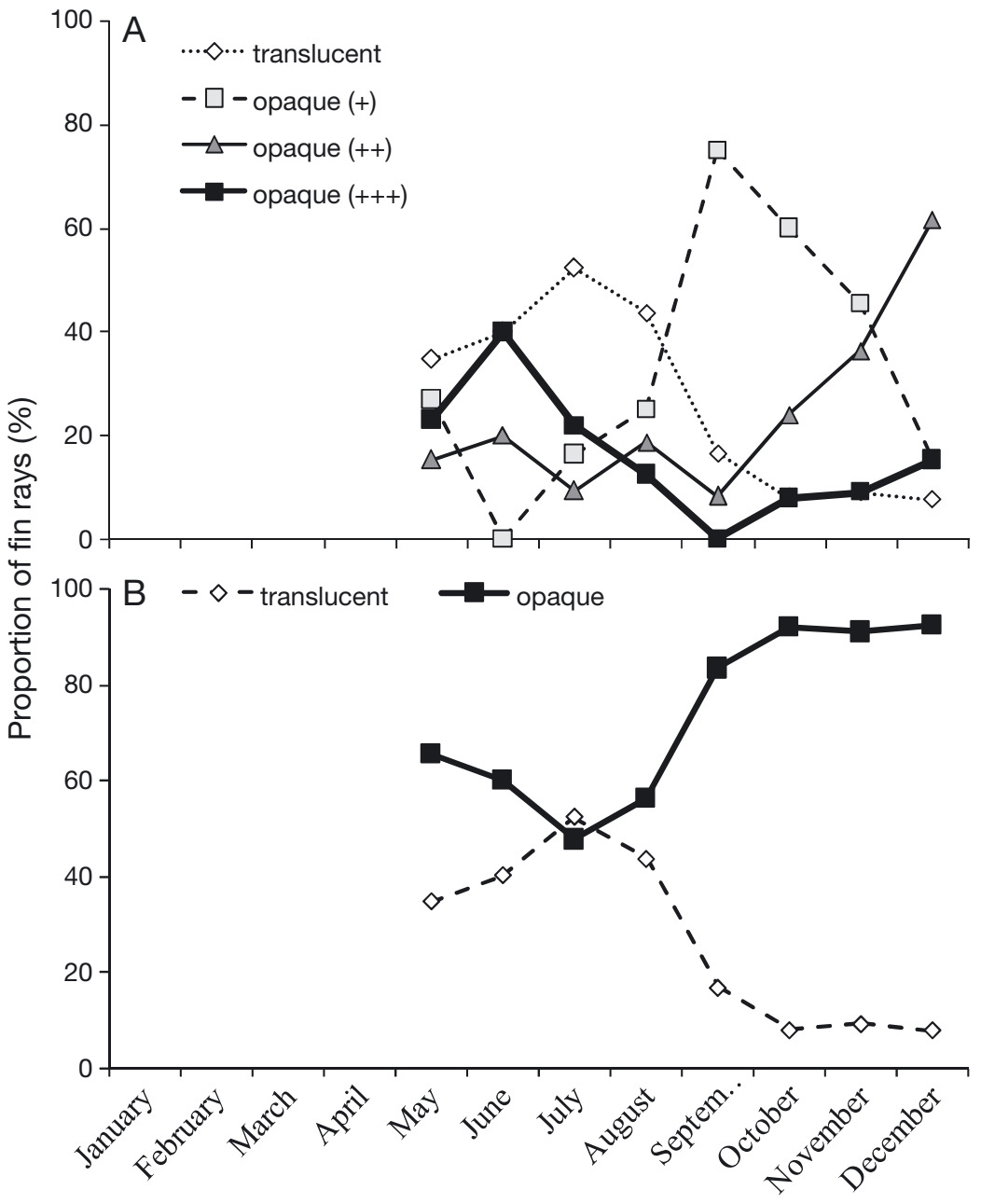

Fig. 4. Validation of the annual deposition of opaque and translucent zones in the fin rays of Atlantic goliath grouper Epinephelus itajara in French Guiana using (A) marginal increments of opaque and translucent zones and (B) edge analysis. For an explanation of,,++++++ see 'Materials and methods: Validation'
Ages were determined for 229 of the 615 fish captured, 11 of which were recaptures. Ages of goliath grouper captured within the MPA ranged between 1 and $10 \mathrm{yr}$, with $94 \%$ of fish between 2 and 6 yr old (Fig. 6). Goliath grouper captured in areas outside the MPA varied between 1 and $17 \mathrm{yr}$ of age, with $89 \%$ of fish between 2 and 7 yr old (Fig. 6). Only 19 goliath grouper were older than 6 yr $(8.5 \%)$ and only 3 were 1 yr old (1.5\%). Age class frequencies were not significantly different between fish captured inside and outside the MPA (Kolmogorov-Smirnov, $\mathrm{p}>0.05$ ).

For those groupers that were only measured and not directly aged using fin rays, age was estimated using agelength keys based on fish caught inside (Table 1) and outside the MPA (Table 2). Age frequency distributions determined from fin rays and ages estimated from age-length keys were not significantly different inside or outside the MPA (Kolmogorov-Smirnov, both p > 0.05; Fig. 7A,B).

\section{Growth}

Ages of all goliath grouper were pooled to estimate an overall growth curve using a von Bertalanffy model. rays necessitated a fourth reading to obtain a resolved age. The reading inconsistencies of fin rays without total agreement were differences of $\pm 1 \mathrm{yr}$ $(24.5 \%), \pm 2 \mathrm{yr}(3.5 \%)$, or $>2 \mathrm{yr}(2.5 \%)$. The ages of young goliath grouper were as difficult to determine as older fish since there was no correlation between the precision of the reading and the age of the fish $\left(\mathrm{r}^{2}<0.01\right)$. There was total agreement between Reader 1 and Reader 2 for $52 \%(\mathrm{CV}=11,7 \%)$ of the fin rays (Fig. 5), with a further $30 \%$ of the fin ray ages within $\pm 1 \mathrm{yr}, 11 \% \pm 2 \mathrm{yr}$, and $7 \%$ with $>2 \mathrm{yr}$.

Fig. 5. Comparison of fin ray ages of Atlantic goliath grouper Epinephelus itajara $(\mathrm{n}=62)$ determined by 2 independent experienced readers. Black circles lying directly on the solid line represent complete agreement between Reader 1 and Reader 2. Dotted line: regression based on ages observed by the 2 readers; circle size: sample size at each age

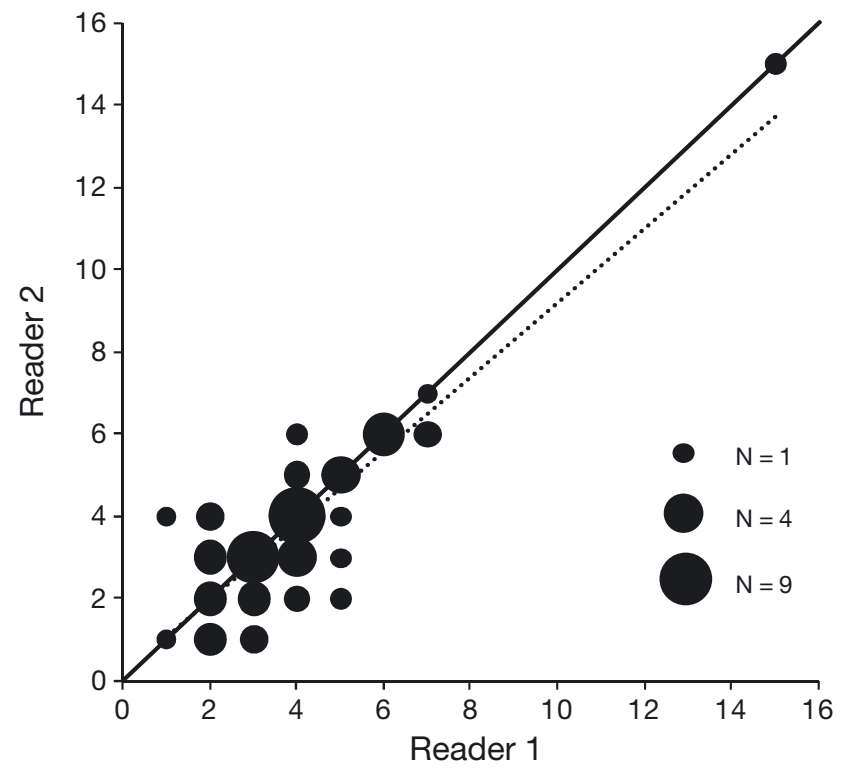




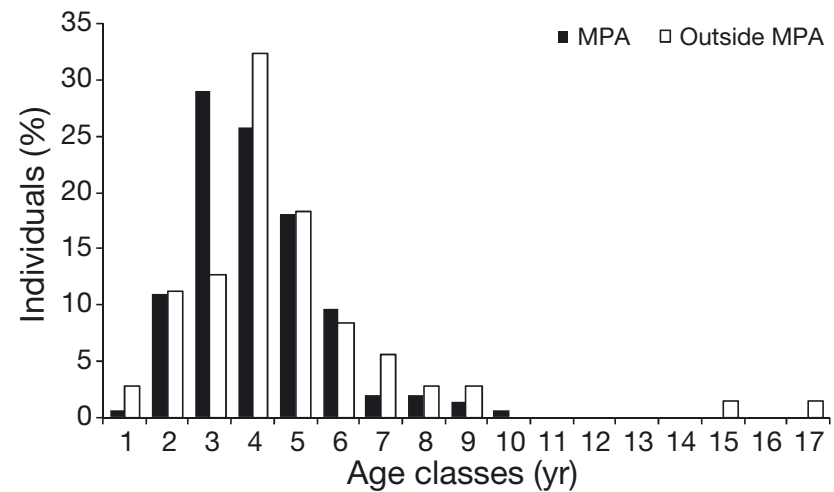

Fig. 6. Age frequencies of Atlantic goliath grouper Epinephelus itajara in French Guiana captured within the boundaries of the Grand Connetable Island marine protected area (MPA) and from areas outside of the MPA that were directly aged using fin rays

Table 1. Age-length key of Atlantic goliath grouper Epinephelus itajara caught inside the Grand Connetable Island marine protected area (MPA), French Guiana, showing percentage of individuals for $10 \mathrm{~cm}$ length classes. First and last length classes were pooled in order to include enough individuals $(\mathrm{N})$ in each class

\begin{tabular}{|c|c|c|c|c|c|c|c|c|c|c|c|}
\hline \multirow{2}{*}{$\begin{array}{l}\text { Length } \\
\text { classes }(\mathrm{cm})\end{array}$} & \multirow{2}{*}{$\mathrm{N}$} & \multicolumn{10}{|c|}{ - Age (yr) } \\
\hline & & 1 & 2 & 3 & 4 & 5 & 6 & 7 & 8 & 9 & 10 \\
\hline $70-89$ & 14 & 7.1 & 42.9 & 42.9 & 7.1 & 0 & 0 & 0 & 0 & 0 & 0 \\
\hline 90-99 & 19 & 0 & 26.0 & 53.0 & 21.0 & 0 & 0 & 0 & 0 & 0 & 0 \\
\hline 100-109 & 15 & 0 & 26.5 & 47.0 & 26.5 & 0 & 0 & 0 & 0 & 0 & 0 \\
\hline 110-119 & 19 & 0 & 5 & 53.0 & 32.0 & 10.0 & 0 & 0 & 0 & 0 & 0 \\
\hline $120-129$ & 19 & 0 & 0 & 47.0 & 37.0 & 16.0 & 0 & 0 & 0 & 0 & 0 \\
\hline $130-139$ & 26 & 0 & 0 & 4.0 & 42.0 & 35.0 & 11.5 & 7.5 & 0 & 0 & 0 \\
\hline 140-149 & 15 & 0 & 0 & 13.0 & 27.0 & 33.0 & 27.0 & 0 & 0 & 0 & 0 \\
\hline 150-159 & 18 & 0 & 0 & 0 & 5.5 & 44.5 & 33.5 & 11.0 & 0 & 5.5 & 0 \\
\hline $160-189$ & 9 & 0 & 0 & 0 & 22.2 & 11.1 & 22.2 & 11.1 & 11.1 & 11.1 & 11.1 \\
\hline
\end{tabular}

Table 2. Age-length key of Atlantic goliath grouper Epinephelus itajara caught on French Guiana fishing sites outside of the marine protected area (MPA), showing percentage of individuals for $10 \mathrm{~cm}$ length classes. First and last length classes were pooled in order to include enough individuals $(\mathrm{N})$ in each class; 2 individuals $>189 \mathrm{~cm}$ were excluded from the key because they were both $>15$ yr old

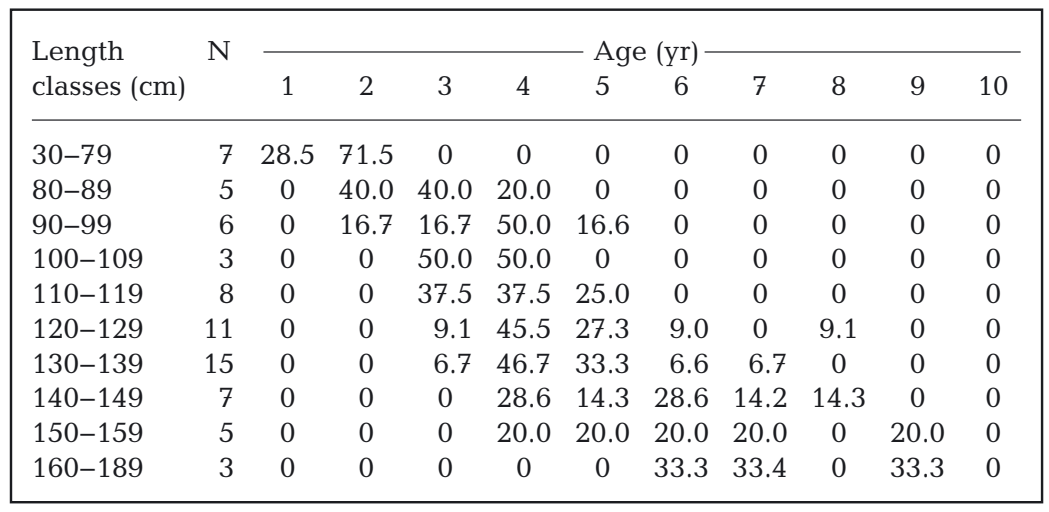

\section{Total mortality}

The age-frequency distributions determined using growth rings on fin rays and using an age-length key not significantly different. Therefore, $Z$ was calby including all individuals caught from 2010 to 2013 , with the exception of the 6 sacrificed individuals (collected for otolith analysis) because different fishing gears were used, which could bias the calculation of $Z$. Total mortality rate inside the MPA $(n=355)$ was 0.66 $\mathrm{yr}^{-1}$, while total mortality outside the MPA ( $\mathrm{n}=254$ ) was 0.64 (Fig. 9); these rates were not significantly different (ANCOVA, slopes: $\mathrm{p}>0.05$; intercept: $\mathrm{p}>0.05$ ). Therefore, it was not possible to distinguish $M$ and $F$ values because it is likely that either the assumptions of (1) equal natural mortality between the 2 areas or (2) little or no fishing mortality in the MPA — or both — do not hold. Mean total mortality rate of goliath grouper in French Guiana was estimated as 0.65 .

\section{DISCUSSION}

Although small juvenile goliath groupers $(<60 \mathrm{~cm}$ TL) have been caught by commercial fishermen using nets, these small fish were not caught (i.e. they were not selected) by our gear; in fact, only a few individuals under $70 \mathrm{~cm}$ were caught. Thus, our samples likely did not reflect the entire juvenile goliath grouper population around rocky sites in French Guiana. The smallest and largest fish of the study were captured outside the MPA. It is possible that the rocky relief of the MPA is not appropriate (rocky wall instead of nooks) to host individuals $<90 \mathrm{~cm}$ (Artero et al. 2015). There may 


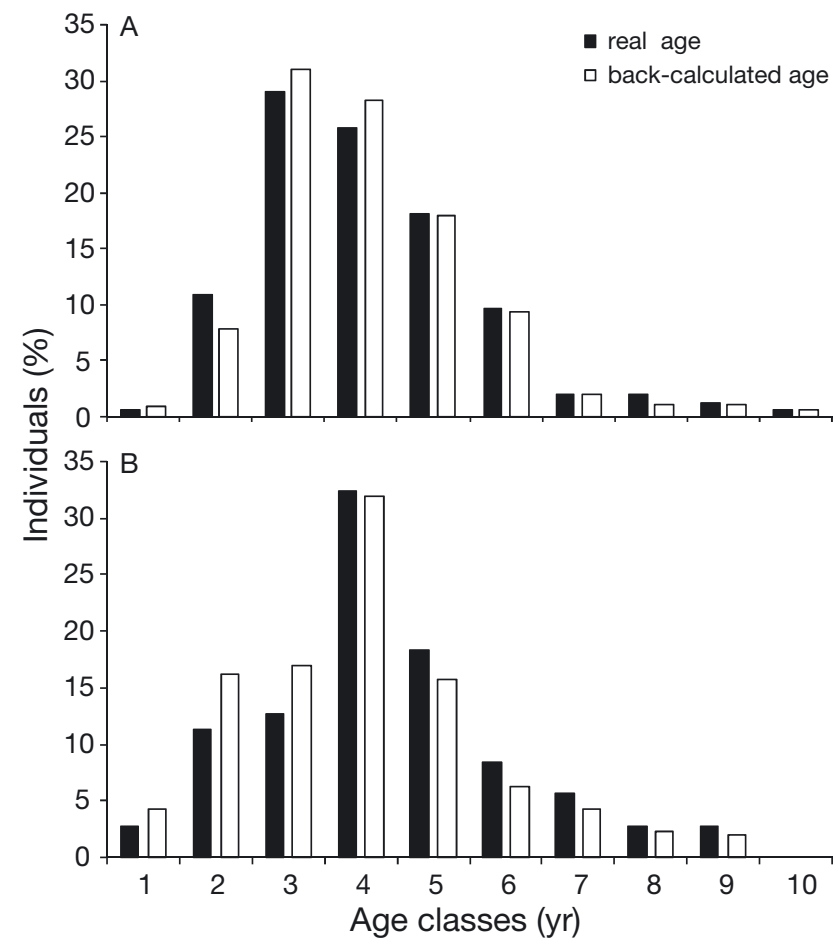

Fig. 7. Frequency of directly aged and estimated ages of Atlantic goliath grouper Epinephelus itajara caught in French Guiana (A) inside the boundary of the Grand Connetable Island marine protected area and (B) outside the MPA

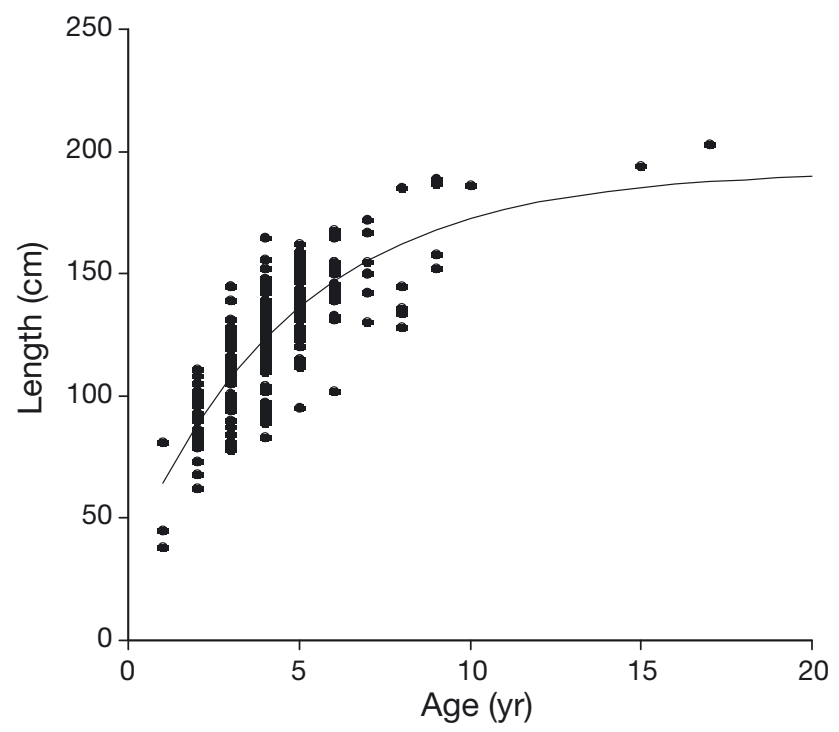

Fig. 8. Fitted von Bertalanffy growth curve based on total length-at-age of Atlantic goliath grouper Epinephelus itajara $(\mathrm{n}=229)$ in French Guiana

also have been a sampling bias toward smaller individuals, as larger individuals are more likely to escape the gear by breaking the fishing line. The largest fish captured for the aging study was $203 \mathrm{~cm}$. A larger goliath grouper $(212 \mathrm{~cm})$ was caught during

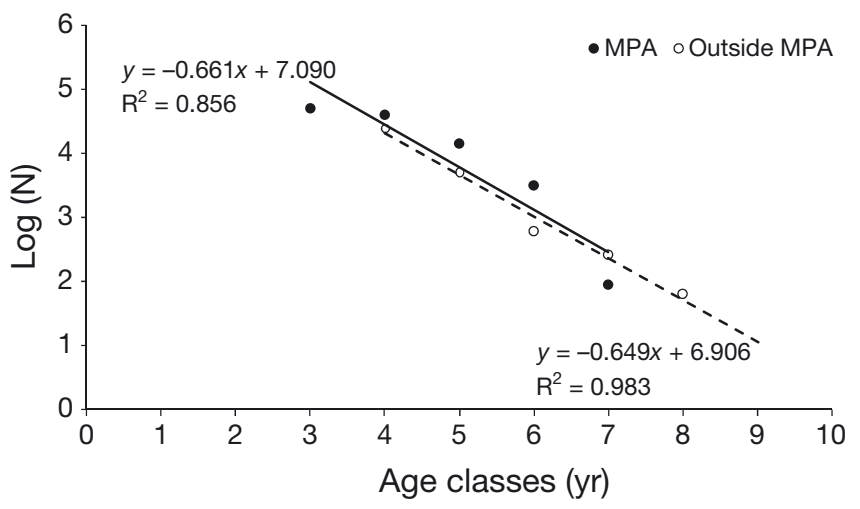

Fig. 9. Total mortality of Atlantic goliath grouper Epinephelus itajara in French Guiana inside the boundary of the Grand Connetable Island marine protected area (MPA) (filled circles with solid regression line) and outside the MPA (open circles with dashed regression line)

the study but its fin rays were not sampled. Commercial landing data did not indicate any goliath grouper caught larger than $200 \mathrm{~cm}$ (G. Karam pers. comm.). Thus, we assume that we had a representative sample of goliath grouper from about 70 to $200 \mathrm{~cm}$ TL.

\section{Use of fin rays for aging Atlantic goliath grouper in a tropical environment}

Based on marginal increment analysis and recaptures, goliath grouper deposit a single annulus each year, with the translucent zone initiated at the start of the dry season (July) and the opaque zone prominent in September through December. Goliath grouper in the eastern Gulf of Mexico deposit opaque zones from April to August (Bullock et al. 1992) as the water temperature increases, earlier than in French Guiana. Marginal increment analysis was not possible after $10 \mathrm{yr}$ of age because annuli were compacted on the edge of the fin ray. Unlike some tropical countries that have 2 wet and 2 dry seasons and corresponding biannuli in fishes (e.g. Rao \& Rao 1986, Admassu \& Casselman 2000, Bwanika et al. 2007), French Guiana only has one rainy season (December to June) and one dry season (July to November). The variation of growth rate of goliath grouper in French Guiana appears to be linked to these seasonal changes, with their deposition of only one complete annulus each year. Annual cycles may depend on the availability of food during these 2 periods, but the diet (diversity and quantity of prey) of goliath grouper does not vary with seasons (Artero et al. 2015). Nevertheless, the fat composition of grouper prey items could vary depending on the season 
(Grigorakis et al. 2002, Zlatanos \& Laskaridis 2007) and might influence their growth rate; unfortunately, this information is not available for French Guiana to affirm or contradict this hypothesis. Growth rate may also vary depending on changes in environmental parameters (temperature, salinity, flux of nutrients) during the rainy season because the Amazon River and local rivers influence the offshore waters around the rocky islands supporting the goliath grouper population (Ffield 2005). Water temperature remains constant throughout the year (Artero 2014) but salinity decreases and nutrient input increases during the rainy season. Since lower salinity and nutrient input promote increases in the growth rate of fish (Johnson \& Katavic 1986, Lambert et al. 1994, Imsland et al. 2001), the growth of goliath grouper in French Guiana should increase during the rainy season, which would correspond to the deposit of the opaque zone.

A total correspondence was found between fin ray ages and otolith ages from the same fish, indicating that fin rays can be as useful as otoliths in determining the age of goliath grouper, even in the tropics. However, more otolith/fin ray comparisons are necessary than the 6 young fish described here in order to determine the accuracy of this method of fin ray aging. Comparisons using older fish ( $>7 \mathrm{yr}$ old) would define the limitations of fin ray aging, as ages of older fish are more difficult to read because of the accumulation of rings on the fin ray margins. Murie et al. (2009) compared otolith and fin ray aging methods for goliath grouper in Florida. Among 21 individuals, $89 \%$ of fin ray ages agreed within a 1 yr difference with otolith ages (from 0 to $17 \mathrm{yr}$ ), although compaction of annuli at the edge of the fin ray structures was also noted in older fish. In Florida, both otoliths and fin rays proved useful structures for aging goliath grouper because annuli could be read relatively easily in both structures. For aging goliath grouper in French Guiana, fin rays were superior to otoliths because opaque zones were poorly defined in the otoliths, with most of the otolith sections appearing translucent despite different section widths. In fin rays, the translucent zones were relatively clear, but checks (false annuli) were present on some rays and were problematic. Checks resulted in a $9 \%$ mean $\mathrm{CV}$, more than twice the variation observed $(\mathrm{CV}=4.24)$ by Murie et al. (2009) in her study of Florida fish. However, total agreement of Reader 1 between the multiple readings was about $70 \%$ once the pattern of checks was recognized. Age agreement among multiple readers was lower than agreement of multiple readings done by a single reader
$(52 \%)$. However, agreement among readers rose to $82 \%$ if agreement was within $\pm 1 \mathrm{yr}$. The percentage of agreement between readings was quite similar to other grouper studies using otoliths (Wyanski et al. 2000, Lombardi-Carlson et al. 2008), indicating reasonable estimates of goliath grouper age in the tropical environment through the use of fin rays.

In the present study, many fin rays were cut too high above their basal structure. This led to difficulty in reading the first annulus (McFarlane \& King 2001, Penha et al. 2004, Murie et al. 2009). In general, the $1 \mathrm{yr}$ difference observed in aging disagreements between readers was due to the difficulty in discerning the first annulus. Future studies should strive to ensure fin rays are sampled as close as possible to their bases. In addition, obtaining fin rays from young-of-the-year and $1 \mathrm{yr}$ old goliath grouper would aid in developing aging criteria for the first annulus.

\section{Age}

Goliath grouper aged by Bullock et al. (1992) ranged from 1 to $37 \mathrm{yr}$ French Guiana samples ranged in age from 1 to $17 \mathrm{yr}$. It is likely that the age of goliath grouper in the eastern Gulf of Mexico exceeds $37 \mathrm{yr}$ because the fish analyzed by Bullock et al. (1992) were collected when the population in Florida was already depleted. The mean age of the goliath grouper population sampled in French Guiana was $4.5 \mathrm{yr}$, suggesting that most individuals in this area are not sexually mature (sexual maturity is reached at approximately 6 yr according to Bullock et al. 1992). Only $8.5 \%$ of fish sampled in this study were older than $6 \mathrm{yr}$, and sexually mature goliath grouper have not been reported from French Guiana. Thus, the population of goliath grouper in French Guiana seems to be principally composed of juveniles. Commercial and recreational fishermen noted the absence of large goliath grouper ( $>2 \mathrm{~m}$ ) over the last few years, but the proportion of large, old fish in the historical population is unknown. Fishing primarily impacts the proportion of large individuals in a population, so fishing in French Guiana could have truncated the age/class distribution of the goliath grouper population to the point where very few adults are now observed. Another explanation for the observation of only a few large, old individuals could be that after reaching maturity, the fish leave the area to join an adult population located elsewhere. This pattern of movement has been observed off southwest Florida, where juveniles move out of the 
mangrove nursery area and may travel to distant sites many km away (Koenig et al. 2011). Both factors (fishing and migration of maturing fish) could be working in concert to truncate the size/age distribution of goliath grouper in the area off French Guiana.

\section{Comparison of growth rates}

Goliath grouper growth curves from fish sampled in French Guiana were compared with those sampled by Bullock et al. (1992) off the southwest coast of Florida (Fig. 10). The estimated average maximum length (i.e. $L_{\infty}$ ) of goliath grouper from French Guiana was $192.3 \pm 11.46 \mathrm{~cm}$ TL. This may be an underestimate since there is such a small sample of larger, older fish in the study and the model fit is below the lengths of all fish $>10$ yr of age, including the maximum length sampled in this study $(203 \mathrm{~cm})$. The largest goliath grouper found in the Bullock et al. (1992) study in the eastern Gulf of Mexico was $206 \mathrm{~cm}$ TL. This individual was aged at $27 \mathrm{yr}$, which is much older than a similar-sized individual in French Guiana (203 cm, 17 yr old). Environmental conditions off French Guiana (high and constant temperature year round, constant abundance of food) could favor faster growth compared to the seasonal changes occurring off southwestern Florida. Indeed, a goliath grouper in French Guiana can be up to 40 cm larger than a similar-aged fish in Florida (Fig. 10). In French Guiana, turbid waters with high nutrient loads are fed by the Amazon River; these waters support a high density of prey for goliath grouper, including crabs, shrimps, and fishes (Miloslavich et al. 2011). In addition, rocky habitats where goliath grouper reside are continuous with mangroves and

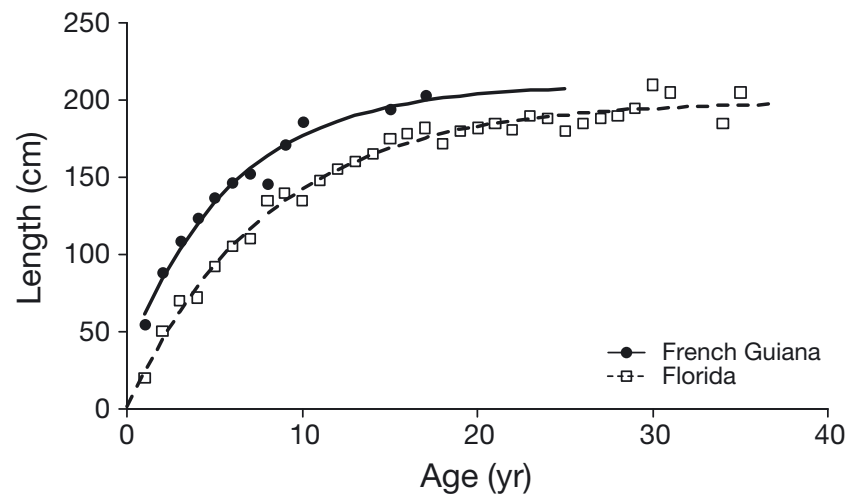

Fig. 10. Mean total length-at-age and fitted von Bertalanffy growth curves for Atlantic goliath grouper Epinephelus itajara from the west coast of Florida ( $\square$ ) (data from Bullock et al. 1992) and French Guiana (•) the estuarine environment; these habitats are characterized by abundant food resources for large predators such as the goliath grouper (Frias-Torres 2006, Koenig et al. 2007).

\section{Mortality}

The total mortality of goliath grouper in French Guiana was estimated inside and outside an MPA in order to determine the intensity of fishing mortality off the coast, assuming that there was no (or very little) illegal fishing inside the MPA and that natural mortality was the same between the 2 areas. The total mortality represents both natural mortality and fishing mortality. However, if there is emigration from the study area as the fish grow, then a basic assumption of catch curve analysis is violated. That is to say that in French Guiana, emigration of older classes of goliath grouper would truncate the catch curve and cause an over-estimation of $Z$. Total mortality estimated for goliath grouper in French Guiana was higher than that of heavily exploited grouper species in the southeastern USA. For example, for red grouper Epinephelus morio, $Z=0.53$ (Burgos \& Defeo 2004) and for snowy grouper Hyporthodus niveatus, $Z=0.57$ (Matheson \& Huntsman 1984). It is therefore necessary to estimate the emigration rate of goliath grouper in the French Guiana population to distinguish between its potential emigration rate versus natural and fishing mortality rates. To date, data on emigration of goliath grouper in French Guiana are limited. Of 600 ind. tagged with plastic dart tags or satellite tags, only 7 moved away from the tagging site and only one appears to have migrated in a westerly direction, but the satellite data were not conclusive (Artero 2014). At this point, then, there is no conclusive evidence of high emigration rates in the study population.

Natural mortality of goliath grouper in French Guiana was not estimable from the MPA data in the present study. However, natural mortality of goliath grouper in the USA was estimated at $M=0.15$ (Sadovy \& Eklund 1999) and then re-evaluated at $M$ $=0.12$ in a more recent stock assessment (SEDAR 2004). Using those estimates, fishing mortality $(F=Z$ $-M$ ) in French Guiana would be 0.53. It is difficult to determine the sustainability of the fishery of goliath grouper in French Guiana without further studies of the emigration of age classes of fish. If $F$ is actually the product of both emigration and fishing mortality, then fishing mortality in French Guiana may be at a sustainable level depending on the emigration rate; 
but if it is not, then it appears urgent to regulate the fishery of this population.

If total mortality estimated inside the MPA were taken at face value, then the population of goliath grouper living within the MPA appears to be as heavily fished as those in fished sites outside the MPA. Indeed, illegal fishing may occur within the MPA, but there is weekly fishing monitoring inside the MPA, so it seems unlikely that it occurs at the same intensity as outside the MPA. Emigration could not explain the equal mortality rates inside and outside the MPA since the same emigration rate should occur in both sites. However, the abundance of goliath grouper in the MPA is 3 times higher than at fished sites, and the scientific fishing rate inside the MPA is 8 times higher than outside the MPA (Artero 2014). One day's fishing by a fisherman illegally targeting goliath grouper in the MPA would reduce the size of the current goliath grouper population by $20 \%$. (Artero 2014). Consequently, even with a low fishing frequency in the MPA ( 4 or 5 fishermen $\mathrm{yr}^{-1}$ ), the high catch rate could lead to the same total mortality rate inside and outside the MPA.

\section{Implications for Atlantic goliath grouper management in French Guiana}

Goliath grouper sampled in French Guiana were aged from 1 to $17 \mathrm{yr}$ old with a mean age of $4.2 \mathrm{yr}$. Only $8.5 \%$ of the individuals were older than $6 \mathrm{yr}$. Based on the age at sexual maturity in the Gulf of Mexico (5 to 6 yr for males and 6 to 7 yr for females; Bullock et al. 1992), $83 \%$ of the goliath grouper population in French Guiana would be estimated to be juveniles. Based on length at sexual maturity (110 to $115 \mathrm{~cm}$ TL for males and 120 to $135 \mathrm{~cm} \mathrm{TL}$ for females), $51 \%$ of the population in French Guiana would be estimated to be juveniles. Considering that the length of goliath grouper in French Guiana is $40 \mathrm{~cm}$ larger than goliath grouper in the eastern Gulf of Mexico for any given age, then age and length at sexual maturity could be different in French Guiana compared to the eastern Gulf of Mexico. Nothing is known about the reproductive biology of this species in French Guiana (age and size at sexual maturity, spawning seasons and sites, etc.) so future studies should focus on reproductive biology. Local fishermen claim to have never seen any eggs or swollen gonads in goliath grouper and no spawning sites have been found to date by scientists or fishermen. There is not enough information available to conclude that the loss of large individuals in French
Guiana is due to overfishing; indeed, much of that loss could be due to emigration.

The impact of commercial and recreational fishing on this population is unknown, but our 'assumed' mortality rates are higher than those for other grouper species. It is possible that some illegal fishing pressure comes from Brazil, where goliath grouper are protected, and/or Surinam, where they are not, but there are no suitable rocky habitats for goliath grouper in Surinam, and their catch there is low (J. Mol pers. comm.).

Size at maturity is likely to be around $150 \mathrm{~cm}$ TL for goliath grouper in French Guiana, the mean size of $6 \mathrm{yr}$ old individuals. Thus a maximum size limit of $150 \mathrm{~cm}$ would seem to be a reasonable management measure. Although seemingly contrary to the conventional minimum size limit regulations, over time such a measure would confirm whether or not large, old fish remain in the near-shore waters of French Guiana or migrate to other unknown sites. Fishermen have reported that larger fish $(>150 \mathrm{~cm})$ were more frequently caught 20 yr ago (G. Karam pers. comm.), so there has probably been some decline in larger fish. If the larger fish spawn in the offshore waters of French Guiana, then protection for large, mature fish might help re-establish old spawning sites, as has occurred in Florida (Koenig et al. 2011).

\section{CONCLUSIONS}

Atlantic goliath grouper were non-destructively aged using fin rays in the equatorial environment of French Guiana. This non-lethal aging method was efficient, even for older fish. However, in future studies care should be taken to excise fin rays close to their base or at their articulation with the pterygiophores so that the earliest annuli may be accurately seen and counted. Otoliths are generally used for aging because they are considered more reliable, but use of otoliths requires killing the fish, which is inappropriate for critically endangered species. The higher growth rate of goliath grouper in French Guiana compared to that determined for the species in the Gulf of Mexico suggests that conditions in French Guiana are better for growth, i.e. consistently warmer temperatures and more abundant food resources. Catch curve analysis for the French Guiana population indicates a mortality rate higher than in any other grouper species. However the as-yet unknown emigration rates might be confounding these high estimates of total mortality. Nevertheless, age determination of about 200 ind. failed to identify 
individuals $>7 \mathrm{yr}$ old. Results from this study are insufficient to develop a long-range plan for the management of goliath grouper in French Guiana, but have identified that an alternative to catch curve analysis will be necessary to estimate mortality, accounting for emigration in the population. A simple approach would be to monitor juvenile populations directly using acoustic technology (Artero 2014) and ban fishing of individuals larger than $150 \mathrm{~cm}$ TL.

Acknowledgements. This study was conducted in partial fulfillment of the degree of Doctor of Marine Biology at the University of French West Indies and French Guiana by C.A. We thank the Grand Connectable Reserve agents, A. Alcide and A. Hauselmann, for providing access to the field and the reserve in their research vessel, the Association des plainsanciers et pêcheurs de Guyane (APPG), especially E. Ribas for his involvement and support in the grouper project, and J. Hargrove for his hospitality in Gainesville (C.A.). We also thank the Direction de l'Environnement, de l'Amenagement et du Logement (DEAL) for supporting the research and the Office National de la Chasse et de la Faune Sauvage for the administrative and financial management of the grouper project.

\section{LITERATURE CITED}

Admassu D, Casselman JM (2000) Otolith age determination for adult tilapia, Oreochromis niloticus L. from Lake Awassa (Ethiopian Rift Valley) by interpreting biannuli and differentiating biannual recruitment. Hydrobiologia 418:15-24

Artero C (2014) Biologie et écologie du mérou géant, Epinephelus itajara, en Guyane française. PhD thesis, Université des Antilles et de la Guyane, Cayenne

> Artero C, Koenig CC, Richard P, Berzins R, Guillou G, Bouchon C, Lampert L (2015) Ontogenetic dietary and habitat shifts in goliath grouper Epinephelus itajara from French Guiana. Endang Species Res 27:155-168

Bullock LH, Murphy MD (1994) Aspects of the life history of the yellowmouth grouper, Mycteroperca interstitialis, in the eastern Gulf of Mexico. Bull Mar Sci 55:30-45

Bullock LH, Smith GB (1991) Seabasses (Pisces: Serranidae). Memoirs of the Hourglass Cruises. Florida Marine Research Institute, St Petersburg, FL

Bullock LH, Murphy MD, Godcharles MF, Mitchell ME (1992) Age, growth and reproduction of jewfish Epinephelus itajara in the eastern Gulf of Mexico. Fish Bull 90: 243-249

Burgos R, Defeo O (2004) Long-term population structure, mortality and modeling of a tropical multi-fleet fishery: the red grouper Epinephelus morio of the Campeche Bank, Gulf of Mexico. Fish Res 66:325-335

> Bwanika GN, Murie DJ, Chapman LJ (2007) Comparative age and growth of Nile tilapia (Oreochromis niloticus L.) in lakes Nabugabo and Wamala, Uganda. Hydrobiologia 589:287-301

Caillart B, Morize E (1989) Étude du rythme de dépôt des microstries sur les otolithes d'un serranidé tropical, Epinephelus microdon (Bleeker), à l'aide d'un marqueur fluorescent: l'oxytétracycline. Aquat Living Resour 2:
255-261

Chapman DG, Robson DS (1960) The analysis of a catch curve. Biometrics 16:354-368

> Coleman FC, Koenig CC, Collins LA (1996) Reproductive styles of shallow-water groupers (Pisces: Serranidae) in the eastern Gulf of Mexico and the consequences of fishing spawning aggregations. Environ Biol Fishes 47: 129-141

Crabtree RE, Bullock LH (1998) Age, growth, and reproduction of black grouper, Mycteroperca bonaci, in Florida waters. Fish Bull 94:735-753

Craig MT (2011) Epinephelus itajara. The IUCN Red List of Threatened Species, version 2014.2. www.iucnredlist. org (accessed 13 Oct 2014)

> Ffield A (2005) North Brazil current rings viewed by TRMM microwave imager SST and the influence of the Amazon plume. Deep-Sea Res I 52:137-160

> Frias-Torres S (2006) Habitat use of juvenile goliath grouper Epinephelus itajara in the Florida Keys, USA. Endang Species Res 2:1-6

Fridriksson A (1934) On the calculation of age-distribution within a stock of cod by means of relatively few agedeterminations as a key to measurements on a large scale. Rapp P-V Reun Comm Int Explor Sci Mer Mediterr 86:1-14

Gerhardinger LC, Bertoncini AA, Hostim-Silva M (2006a) Local ecological knowledge and goliath grouper spawning aggregations in the South Atlantic Ocean: goliath grouper spawning aggregations in Brazil. Trad Mar Res Manage Know Inf Bull 20:33-34

Gerhardinger LC, Marenzi RC, Bertoncini ÁA, Medeiros RP, Hostim-Silva M (2006b) Local ecological knowledge on the goliath grouper Epinephelus itajara (Teleostei: Serranidae) in southern Brazil. Neotrop Ichthyol 4:441-450

Grigorakis K, Alexis MN, Taylor KDA, Hole M (2002) Comparison of wild and cultured gilthead sea bream (Sparus aurata); composition, appearance and seasonal variations. Int J Food Sci Technol 37:477-484

Hostim-Silva M, Bertoncini AA, Gerhardinger LC, Machado LF (2005) The 'lord of the rock's' conservation program in Brazil: the need for a new perception of marine fishes. Coral Reefs 24:74

Imsland AK, Foss A, Gunnarsson S, Berntssen MHG and others (2001) The interaction of temperature and salinity on growth and food conversion in juvenile turbot (Scophthalmus maximus). Aquaculture 198:353-367

Johnson DW, Katavic I (1986) Survival and growth of sea bass (Dicentrarchus labrax) larvae as influenced by temperature, salinity, and delayed initial feeding. Aquaculture 52:11-19

Kimura DK, Lyons JJ (1991) Between-reader bias and variability in the age-determination process. Fish Bull 89: 53-60

Koenig CC, Coleman FC (2009) Population density, demographics and predation effects of adult goliath grouper. MARFIN project NA05NMF4540045 final report, NOAA, Miami, FL

Koenig CC, Coleman FC (2013) The recovering goliath grouper population of the southeastern US: nonconsumptive investigations for stock assessment. MARFIN project NA10NMF4330123 final report, NOAA, Miami, FL

Koenig CC, Coleman FC, Eklund AM, Schull J, Ueland J (2007) Mangroves as essential nursery habitat for goliath grouper (Epinephelus itajara). Bull Mar Sci 80:567-586 
Koenig CC, Coleman FC, Kingon K (2011) Pattern of recovery of the goliath grouper Epinephelus itajara population in the southeastern US. Bull Mar Sci 87: 891-911

Lambert Y, Dutil JD, Munro J (1994) Effects of intermediate and low salinity conditions on growth rate and food conversion of Atlantic cod (Gadus morhua). Can J Fish Aquat Sci 51:1569-1576

Lombardi-Carlson L, Fitzhugh G, Palmer C, Gardner C, Farsky R, Ortiz M (2008) Regional size, age and growth differences of red grouper (Epinephelus morio) along the west coast of Florida. Fish Res 91:239-251

Matheson RH, Huntsman GR (1984) Growth, mortality, and yield-per-recruit models for speckled hind and snowy grouper from the United States South Atlantic Bight. Trans Am Fish Soc 113:607-616

McClenachan L (2009) Historical declines of goliath grouper populations in South Florida, USA. Endang Species Res 7:175-181

McFarlane GA, King JR (2001) The validity of the fin-ray method of age determination for lingcod (Ophiodon elongatus). Fish Bull 99:459-464

Miloslavich P, Klein E, Diaz JM, Hernandez CE and others (2011) Marine biodiversity in the Atlantic and Pacific coasts of South America: knowledge and gaps. PLoS ONE 6:e14631

Murie DJ, Parkyn DC, Koenig CC, Coleman FC, Schull J, Frias-Torres S (2009) Evaluation of fin-rays as a nonlethal ageing method for protected goliath grouper Epinephelus itajara. Endang Species Res 7:213-220

NMFS (National Marine Fisheries Service) (2006) Status report on the continental United States distinct population segment of the goliath grouper (Epinephelus itajara), Florida. National Marine Fisheries Service, St. Petersburg, FL

Pauly D (1990) Length-converted catch curves and seasonal growth of fishes. Fishbyte 8:24-29

Editorial responsibility: Nicholas Tolimieri, Seattle, Washington, USA
Penha JMF, Mateus LAF, Petrere MP Jr (2004) A procedure to improve confidence in identification of the first annulus in fin-spines of fishes. Fish Manage Ecol 11:135-137

Rao DM, Rao KS (1986) Studies on the age determination and growth of Nemipterus japonicus (Bloch) off Visakhapatnam. Indian J Fish 33:426-439

Ricker WE (1975) Computation and interpretation of biological statistics of fish populations. Bull Fish Res Board Can 191:1-382

Sadovy Y, Eklund AM (1999) Synopsis of biological data on the Nassau grouper, Epinephelus striatus (Bloch, 1792), and the jewfish, E. Itajara (Lichtenstein, 1822). NOAA Tech Rep NMFS 146, US Department of Commerce, Seattle, WA

Sadovy Y, Severin KP (1992) Trace elements in biogenic aragonite: correlation of body growth rate and strontium levels in the otoliths of the white grunt, Haemulon plumieri (Pisces: Haemulidae). Bull Mar Sci 50:237-257

Sadovy Y, Shapiro DY (1987) Criteria for the diagnosis of hermaphroditism in fishes. Copeia 1987:136-156

SEDAR (Southeast Data Assessment and Review) (2004) Complete stock assessment report of SEDAR 6: goliath grouper. SEDAR6-SAR1 assessment report 1, Southeastern Data Assessment and Review, Charleston, SC

Shapiro DY (1987) Reproduction in groupers. In: Polovina JJ, Ralston S (eds) Tropical snappers and groupers: biology and fisheries management. Westview Press, Boulder, CO, p 295-327

Wyanski DM, White DB, Barans CA (2000) Growth, population age structure, and aspects of the reproductive biology of snowy grouper, Epinephelus niveatus, off North Carolina and South Carolina. Fish Bull 98:199-218

Zlatanos S, Laskaridis K (2007) Seasonal variation in the fatty acid composition of three Mediterranean fish - sardine (Sardina pilchardus), anchovy (Engraulis encrasicholus) and picarel (Spicara smaris). Food Chem 103: 725-728

Submitted: February 24, 2012; Accepted: May 23, 2012

Proofs received from author(s): September 18, 2015 